\section{Dr. L. G. M. Baas-Becking}

Lourens Gerhard Marinus BaAs-Becking was born on January 4, 1895, in Deventer in the Netherlands. After his secondary schooling in Amersfoort and a preliminary year at the Technical College in Delft, he studied botany in the University of Utrecht, where he received his A.B. and M.A. In 1918 he married Bien Haverman and together they left for California, which provided a better climate for his asthma. Throughout his life, BaasBecking had a frail constitution, but through his iron will he always remained master over his body and even survived a vicious typhus infection while a German prisoner during the War. In California he completed his botanical study with a thesis on "Studies on Stelar Development" under Douglas Campbell, and in 1924 was appointed professor of biology and later worked in the Hopkins Marine Station in Pacific Grove. During these years in California he developed his full potentialities of imaginative development of basic ideas. In 1921 he also received a doctorate at the University of Utrocht for a thesis on "Radiation and Vital Phenomena". In 1930 BaasBecking returned to the Netherlands as professor of botany in the University of Leyden, where the botanical laboratory became the centre of unprecedented activity. He succeeded in drawing a large group of graduato students working over a wide range of botanical subjects and he succeeded in the renovation of the botanical garden and its greonhouses. In 1939 Baas-Becking was asked to reorganize the famous botanical garden at Bogor, Java, and in 1940 was appointed its director. While winding up his work in Holland he was caught by the German invasion. Immediately after his liberation and recovery from his prison experiences he moved with the first Dutch groups into Java. There he organized mobile Red Cross teams, and with unlimited energy and courage he travelled through bandit-infested areas and saved. numberless people during those troubled times.

With the transfer of the sovereignty over Java to the Indonesian Republic, the Indonesians appointed another director of the Gardens, and Baas-Becking left Java and became director of research of the South Pacific Commission and for some years organized the work of this Commission with headquarters in Noumea. After the tragic death of his wife, Baas-Becking moved to Australia, where he became connected with the Commonwealth Scientific and Industrial Research Organization, first in the Fisheries Station in Crcnulla and later in Canberra, where he died on January 6, 1963, after a long illness, depriving him of free communication with his fellow-man, but not impairing his mental alertness. The devoted help of Mrs. Johanna Bombeeck, whom he married in 1961, made those last difficult years more tolerable.

The effect of Baas-Becking on botanical sciences has been largely through his students and collaborators. He, himself, had too mercurial a mind to enter into the details necessary to establish beyond doubt, through tedious research work, the principles which sprouted from his fertile mind. In 1932 he published a most interesting book on Geobiology, which did not find a wide audience because it was written in Dutch. During his stay in Australia he worked this into an extensive English manuscript which unfortunately has never boen published. A sort of scientific testament of Baas-Becking can be found in Contributions to Marine Microbiology, Information Series No. 22 of the New Zealand Department of Scientific and Industrial Research.

Baas-Becking's main fiold of interest was the relationship between organism and environment, and their mutual dependence. He was particularly interested in saline environments, how they developed, and the organisms living in them. He was also one of the pioneers in the field of molecular biology with his early papers on sulphur bacteria and the application of thormodynamics to their metabolism. He and his students pioneered in the molecular arrangement of chlorophyll in the chloroplast, and the model they developed is still essentially the accepted one. His interest in practical applications of science was evident, when he acted as adviser for Governments and private companies on such diverse subjects as salt production, food quality, herbicides and economic problems. In addition, his interests in historical problems found expression in articles and a delightful book, Hortus Lugduno Batavus (1937).

Baas-Becking had a brilliant mind with potentialities of genius. Nothing was more stimulating than a few hours or days with him. He was exceedingly well read and had considerable mathematical training and ability. On every subject, whether biological or other, he had original points of view and approaches. Unfortunately, his intolerance of mediocrity and very sharp and often over-critical tongue alienated a large number of people; for no one could be neutral in his appreciation of BaasBecking: one was either a great admirer or an enemy. It is certain that through his many admirers and students his adventuresome spirit and his unconventional but deep-probing approach to problems of life and of science will continue to play a part in the progress of science and of mankind.

F. W. WENT

\section{Prof. Bertil Lindquist}

Prof. Bertil Lindquist died on February 4, and both Swedish botany and world forestry have lost an outstanding man. He was in his fifty-ninth year and had known for years that he was stricken with a deadly disease; but this did not stop him from travelling widely and continuing to make a most distinguished contribution to botany and forestry.

The outstanding quality of Bertil Lindquist was the breadth of his interest which ranged from forest genetics through ecology and forest entomology to the cultivation of rare orchids. In 1931 he was appointed to a lectureship at the Swedish Royal School of Forestry and his publications in 1932 included studies of the races of elm, the natural regeneration of Norway spruce, the taxonomy of Juncus alpinus and the beech forests of Sweden. Lindquist then became interested in the pioneer tree hybridization work of Dengler in Germany and Syrach Larsen in Denmark and saw a great future for the application of genetics in forest practice. The Forest Tree Breeding Association of Sweden began functioning in 1938 and three years later a group of forestry companies joined to form the Society of Practical Forest Improvement with Lindquist as director. $\mathrm{He}$ carried on this work concurrently with his teaching post until 1945 .

In 1946 Lindquist was appointed professor of silviculture in the Royal School of Forestry and he held this post until 1950. This period saw the publication of a series of important papers on racial and individual tree variation in birch and culminated in the fine work Genetics in Swedish Forestry Practice in which he described in detail a programme of practical tree improvement. Lindquist's work during his time at Stockholm has had a great influonce on the development of forest genetics and tree breeding. His high standard of writing and presentation has stimulated many people in their first steps in tree breeding.

The next and final step in Bertil Lindquist's career was the move in 1950 to the directorship of the important Botanical Garden in Gothenburg. He continued his interests in forest genetics and tree breeding and made the pages of the handsomely produced Acta Horti Gotoburgensis available for a valuablo series of papers on seed orchards, clonal trials and racial variation. His own interests became general once more. A journey to Japan in 1954 led to an important account of Japanese lareh and a paper of 1959 returned to an earlier theme of forest. 